\title{
Surgical management of retinal detachment associated with the acute retinal necrosis syndrome
}

\author{
H Richard McDonald, Hilel Lewis, Allan E Kreiger, Yossi Sidikaro, John Heckenlively
}

\begin{abstract}
We operated on nine eyes in eight patients with retinal detachment associated with acute retinal necrosis (ARN) syndrome. The patients were treated with scleral buckling, vitreoretinal surgery, or a combination of these treatments. Vitrectomised eyes underwent combinations of lensectomy, membrane dissection, scleral buckling, air-fluid exchange, endolaser photocoagulation, cryotherapy, and retinal tamponade with $\mathrm{C}_{3} \mathbf{F}_{8}$ gas or $\mathrm{SF}_{6}$ gas. Macular attachment was achieved in eight $(89 \%)$ eyes. Vision improved in seven (78\%) eyes, of which five $(56 \%)$ achieved $20 / 200$ or better vision. Three eyes that had received laser treatment posterior to areas of retinitis suffered retinal detachment despite this prophylactic treatment. Poor visual outcome resulted from viral infection of the optic nerve or macular involvement, macular hole formation, macular pucker, or hypotony.
\end{abstract}

Acute retinal necrosis (ARN) is a clinically defined syndrome characterised by confluent, peripheral necrotising vaso-occlusive retinitis, arteritis, and vitritis. ${ }^{1-10}$ Although this syndrome was first described in healthy individuals, immunocompromised patients may also be affected. ${ }^{11-13}$ Herpes viruses have been implicated as causal agents in ARN. ${ }^{12-23}$ Retinal detachment is a frequent complication of the syndrome. The incidence of retinal detachment depends on the extent of peripheral retinal involvement and the degree of vitritis. It has been reported to be as high as $85 \%$, despite the efficacy of acyclovir in hastening the resolution of the retinitis. ${ }^{124-29}$

Measures for the prevention or treatment of retinal detachment in eyes with ARN have included prophylactic photocoagulation, 9242530 prophylactic vitrectomy and scleral buckling with acyclovir infusate during the acute phase of the retinitis, ${ }^{29} 31$ scleral buckling alone,${ }^{32}$ and pars plana vitrectomy, endolaser photocoagulation, and long-acting retinal tamponade. $.^{24} 2932-34$

We report here our surgical results for retinal detachment associated with the acute retinal necrosis syndrome.

Jules Stein Eye Institute and Department of Ophthalmology,

University of California

Los Angeles, Los

Angeles, California

H Lewis

A E Kreiger

Y Sidikaro

J Heckenlively

Correspondence to:

H Richard McDonald, MD One Daniel Burnham Court Suite 210, San Francisco, CA 94109 , USA.

Accepted for publication 8 March 1991

Patients and methods

Between 1981 and 1988 we operated on nine eyes of eight patients with retinal detachments associated with the acute retinal necrosis syndrome. Five of the eight patients were females, three males; they ranged in age from 16 to 73 years, mean $40 \cdot 1$ years. Follow-up ranged from nine months to five years, mean 18 months.

Seven of the eight patients were treated with the development of retinal detachment. These patients were also treated with prednisone and aspirin during their time in hospital. In patients who were treated with prophylactic photocoagulation in an attempt to prevent the occurrence of posterior pole retinal detachment, three to six contiguous rows of laser photocoagulation burns were placed posterior to the confluent peripheral retinitis. Retinal detachment developed following large retinal breaks at the border of necrotic retina in seven eyes. One eye had a retinal break within an area of active retinitis (case 2), and one eye developed a break in the uninvolved retina (case 9). Three eyes underwent scleral buckling alone, while six éyes underwent vitreous surgery.

Those patients undergoing vitreoretinal surgery were operated on by the bimanual technique with a posterior infusion port and fibreoptic illumination. Meticulous anterior vitreous base vitrectomy, with $360^{\circ}$ scleral depression, was part of each vitrectomy. Epiretinal membranes were dissected from the retinal surface and removed from each of these eyes.

Encircling scleral buckles were placed in all eyes that had vitreous surgery, not to support specific retinal breaks but to relieve peripheral anterior vitreous base contraction that might occur during the postoperative period. Vitrectomised eyes had air-fluid exchange with internal subretinal fluid drainage by means of preexisting breaks or planned retinotomies. Confluent endolaser photocoagulation was used to treat the edge of attached uninfected retina posterior to the peripheral retinitis. Photocoagulation was also applied round all retinotomy sites and over the scleral buckle. Vitreous substitution with sulphur hexafluoride gas (25\%), or perfluoropropane gas (20\%) was then performed.

\section{Results}

Nine eyes of eight patients underwent surgery for retinal detachment associated with the acute retinal necrosis syndrome (Table 1). Macular reattachment was achieved in eight $(89 \%)$ of them.

Two of the nine eyes had partial retinal reattachment. One eye with partial retinal attachment developed postoperative epiretinal membranes that detached a quadrant of extraacyclovir either before or concurrently with macular retina and puckered the macula. The patient declined further surgery. The other such eye developed anterior retinal detachment due to anterior proliferative vitreoretinopathy, though the posterior retina remained attached.

Vision improved to the 20/200 level in five $(56 \%)$ of nine eyes. Of the eight eyes in which the retina was reattached one had no light perception because of optic nerve involvement. 
Table 1 Surgical results in acute retinal necrosis

\begin{tabular}{|c|c|c|c|c|c|c|c|c|c|c|}
\hline Case & Age & Sex & $\begin{array}{l}\text { Preop } \\
\text { laser }\end{array}$ & $\begin{array}{l}\text { Preop } \\
\text { vision }\end{array}$ & Acyclovir & Surgery & $\begin{array}{l}\text { Postop } \\
\text { vision }\end{array}$ & $\begin{array}{l}\text { Anatomical } \\
\text { result }\end{array}$ & $\begin{array}{l}\text { Follow- } \\
\text { up }\end{array}$ & Comments \\
\hline 1 & 27 & $\mathbf{F}$ & + & $3 / 200$ & + & $\begin{array}{l}\mathrm{L}, \mathrm{V}, \mathrm{M}, \underset{\mathrm{AFX}}{\mathrm{E}, \mathrm{SB}, \mathrm{C}_{3} \mathrm{~F}_{8}}\end{array}$ & $5 / 200$ & Attached & $24 \mathrm{mths}$ & $\begin{array}{l}\text { 1. Developed peripheral RD, then PVR. } \\
\text { Previous herpes zoster uveitis in other eye } \\
\text { 2. Developed macular pucker postop, declined } \\
\text { further surgery }\end{array}$ \\
\hline 2 & 35 & $\mathbf{F}$ & - & HM & + & $\begin{array}{l}\mathrm{L}, \mathrm{V}, \mathrm{M}, \mathrm{AFX} \\
\mathrm{E}, \mathrm{C}_{3} \mathrm{~F}_{8}, \mathrm{SB}\end{array}$ & $20 / 200$ & Attached & $12 \mathrm{mths}$ & $\begin{array}{l}\text { 1. Active retinitis and RD } \\
\text { 2. Acyclovir (IV, and infusate } 40 \mu \mathrm{g} / \mathrm{ml} \text { ) } \\
\text { 3. Giant retinotomies created during surgery } \\
\text { 4. Hypotony retinopathy, IOP normal } 3 \mathrm{mths} \\
\text { postop }\end{array}$ \\
\hline 3 & 36 & $\mathbf{M}$ & + & $7 / 200$ & + & $\begin{array}{l}\text { V, M, AFX, E, } \\
\mathrm{C}_{3} \mathrm{~F}_{8}, \mathrm{SB} \\
\mathrm{SB}\end{array}$ & $20 / 160$ & Attached & $12 \mathrm{mths}$ & $\begin{array}{l}\text { 1. Developed posterior epiretinal membranes } \\
\text { and macular hole } \\
\text { 2. Increased nuclear sclerosis }\end{array}$ \\
\hline $\begin{array}{l}4 \\
5\end{array}$ & $\begin{array}{l}73 \\
51\end{array}$ & $\underset{M}{\mathrm{~F}}$ & $\overline{-}$ & $\begin{array}{l}20 / 400 \\
20 / 300\end{array}$ & + & $\begin{array}{l}\text { SB (segmental) } \\
\text { V, C, AFX, SB, } \\
\text { SF }_{6}\end{array}$ & $\begin{array}{l}\text { NLP } \\
20 / 80\end{array}$ & $\begin{array}{l}\text { Attached } \\
\text { Attached }\end{array}$ & $\begin{array}{l}12 \text { mths } \\
36 \text { mths }\end{array}$ & $\begin{array}{l}\text { 1. Optic nerve involvement caused NLP } \\
\text { 1. Cataract developed, later removed } \\
\text { 2. Treated before availability of endolaser }\end{array}$ \\
\hline 6 & 16 & $\mathbf{F}$ & - & $\mathbf{H M}$ & - & $\begin{array}{l}\text { 1. V, SB, C, SF } \\
\text { 2. L,V,M, AFX, } \\
\text { E, SF }\end{array}$ & $6 / 200$ & Attached & $24 \mathrm{mths}$ & $\begin{array}{l}\text { 1. Developed postop ERM, and became } \\
\text { redetached } \\
\text { 2. Postop hypotony associated with anterior } \\
\text { PVR }\end{array}$ \\
\hline 7 & 16 & $\mathbf{F}$ & - & $20 / 25$ & + & SB & $20 / 20$ & Attached & $18 \mathrm{mths}$ & $\begin{array}{l}\text { 1. OD of case } 6 \\
\text { 2. Encircling scleral buckle for quadrantic RD }\end{array}$ \\
\hline 8 & 36 & $\mathbf{F}$ & - & $\mathbf{H M}$ & - & $\begin{array}{l}\mathrm{L}, \mathrm{V}, \mathrm{M}, \mathrm{AFX} \\
\mathrm{C}, \mathrm{SF}_{6}, \mathrm{SB}\end{array}$ & NLP & Detached & 60 mths & $\begin{array}{l}\text { 1. Prior to accepted use of acyclovir } \\
\text { 2. Had VH due to neovascularisation } \\
\text { 3. Developed proliferative vitreoretinopathy } \\
\text { postoperatively and declined reoperation }\end{array}$ \\
\hline 9 & 63 & $\mathbf{M}$ & + & HM & + & SB & $20 / 60$ & Attached & 9 mths & $\begin{array}{l}\text { 1. Break in uninfected retina, outside } \\
\text { demarcated area }\end{array}$ \\
\hline
\end{tabular}

V: pars plana vitrectomy. $M$ : membranectomy. L: lensectomy. AFX: air-fluid exchange. E: endolaser photocoagulation. $C$ : cryotherapy. SB: scleral buckle. $C_{3} F_{8}$ : perfluoropropane gas. SF : sulphur hexafluoride. S: silicone oil. RD: retinal detachment. PVR: proliferative vitreoretinopathy. PR: pneumatic retinopexy. ERM: epiretinal membranes. VH: vitreous haemorrhage. HM: hand movements. CF: counting fingers. LP: light perception. NLP: no light perception.

Three eyes had preoperative prophylactic laser posterior to the areas of retinitis. In two of these eyes the retina was treated for $360^{\circ}$. In one eye (case 9) the peripheral retinitis did not involve the entire periphery, and laser was placed round the infected retina, extending anteriorly to the ora serrata. Despite the prophylactic laser, the retina in these three eyes became detached, but was successfully reattached with surgery.

\section{Discussion}

Retinal detachment remains a serious complication of the acute retinal necrosis syndrome. As surgical techniques for dealing with complicated retinal detachment have become more refined, the reattachment rate has improved. ${ }^{14} 291^{31-34}$ The visual acuity results have not been as satisfactory, though recently Blumenkranz et al reported that five of six eyes achieved 20/200 or better vision after successful repair. ${ }^{32}$

In our series the retina was reattached partially or totally in eight (89\%) of nine eyes. Of the two eyes with partial attachment one (case 1) developed postoperative epiretinal membrane formation and macular ectopia and the patient refused further surgery. In the third patient (case 6 , OS), the entire posterior pole was reattached. Nevertheless, anterior proliferative vitreoretinopathy redetached the periphery and probably played a part in the patient's postoperative hypotony.

Though vision improved in seven $(78 \%)$ eyes, it did so to $20 / 200$ or better in only five $(56 \%)$. In three eyes the retina was reattached, yet vision failed to reach the 20/200 level. These eyes were thought to have associated complications that prevented significant visual improvement, including postoperative macular pucker (case 1), optic neuritis, presumed to be secondary to herpes virus (case 4), and hypotony following reoperation for proliferative vitreoretinopathy (case 6, OS).
Several authors have suggested that in eyes with clear enough vitreous to allow laser, prophylactic photocoagulation should be used to demarcate areas of active retinitis in an attempt to decrease the incidence of posterior retinal detachment. ${ }^{942530}$ In our series three eyes had prophylactic laser treatment but developed posterior retinal detachment. In one of these eyes (case 9) the break developed outside the area of demarcated retina, presumably in uninfected retina. In case 1 proliferative vitreoretinopathy (PVR) developed and tractionally detached the retina away from the lasered area. Case 3 also developed PVR with an associated macular hole that resulted in posterior retinal detachment.

There appears to be a spectrum of disease severity with the acute retinal necrosis syndrome. Some eyes have fulminant disease requiring advanced vitreous microsurgery, while others have only a mild manifestation of the disease. ${ }^{35}$ Some eyes with retinal detachment and ARN can be successfully managed with scleral buckling; two were encircled, and one received only a segmental buckle. Scleral buckling, therefore, may be considered a surgical alternative in mild cases with small breaks, quadrantic involvement, and minimal vitritis..$^{2+33}{ }^{34}$ The majority of ARN cases, however, have multiple, large posterior breaks that are best treated with vitreoretinal surgery.

Good anatomical success rates and visual results have been reported with vitrectomy techniques without scleral buckling. ${ }^{32}$ In our series six eyes underwent vitrectomy in combination with various adjunctive procedures (Table 1 ). No eyes underwent vitrectomy without placement of a scleral buckle.

In most patients requiring vitrectomy for retinal detachment with $A R N$ the lens needs to be removed. This allows easy access to the far anterior peripheral vitreous base. If this peripheral vitreous is allowed to remain, it may contract postoperatively and redetach the retina. ${ }^{32}$ Place- 
ment of an encircling scleral buckle, combined with meticulous vitreous base dissection, may minimise this complication.

In one eye (case 6, OS) anterior retinal detachment and hypotony developed postoperatively, though the posterior retina was attached. In this case the lens was not removed at the time of the second operation. Another reason for removing the lens is the likelihood of developing a cataract with the use of long-acting gas substitutes or silicone oil. In our series two patients (cases 3 and 5) underwent vitrectomy without lensectomy. Both developed cataracts within several months, requiring cataract surgery.

Short-acting $\left(\mathrm{SF}_{6}\right)$ and long-acting $\left(\mathrm{C}_{3} \mathrm{~F}_{8}\right)$ gases were used as vitreous substitutes for retinal tamponade following retinal reattachment with air-fluid exchange (Table 1 ).

Hypotony was a postoperative complication in two patients with successful retinal reattachment (cases 2, 6, OS). In case 2 the retina was reattached and the eye had a normal intraocular pressure (IOP) for several weeks. Vision improved to the 20/128 level. The IOP fell to zero over several weeks and the fundus developed chorioretinal folds, retinal striae, and a boggy, thickened appearance. The vision dropped to $9 / 200$. There was no significant intraocular inflammation at this time, nor was there any anterior proliferative response that might have created ciliary body detachment. After injections of retrobulbar steroids over a three-month period, the IOP rose to $10 \mathrm{~mm} \mathrm{Hg}$ and vision improved to 20/200. The other patient who developed hypotony (case 6, OS) had traction on the ciliary body created by anterior PVR. ${ }^{36}$

Retinal detachment usually occurs after the acute period of retinal necrosis has passed. The infected necrotic retina thins, so that only a fibroglial remnant remains over the disrupted retinal pigment epithelium in many areas. The vitreous develops various degrees of haziness and inflammatory opacification related to the severity and extent of retinitis, and also related to the immune system's ability to mount a response. The subsequent contraction of the vitreous creates traction on the retina, and large retinal breaks usually form at the borders of the involved and uninvolved retina. One of our cases (case 2) developed a retinal detachment during the acute phase of the retinitis. This eye had partial posterior vitreous separation and retinal breaks within the area of active retinitis. Surgery on such eyes is difficult because of the iatrogenic retinal breaks created by removing areas of attached vitreous from necrotic, detached retina.

Because retinal breaks usually occur when the contracting vitreous tears the necrotic, avascular retina, significant vitreous haemorrhage is not common in ARN. Vitreous haemorrhage can occur, however, in association with neovascularisation created by the inflammatory and ischaemic conditions prevalent in ARN. ${ }^{37} 38$ Panretinal photocoagulation to areas of non-necrotic and segmentally non-perfused retina has been shown to cause regression of optic nerve neovascular proliferation. ${ }^{39}$ One eye in our series (case 8) had retinal detachment and vitreous haemorrhage caused by neovascularisation. At the time of surgery the retina behind the vitreous haemorrhage was found to be totally necrotic. Postoperatively the retina became detached again and the eye was eventually enucleated. This patient's other eye also had ARN and disc neovascularisation that responded well to panretinal photocoagulation.

The acute retinal necrosis syndrome may be complicated by retinal detachment. For those eyes with small or single breaks and quadrantic detachments, scleral buckling may be sufficient to reattach the retina. If complicated retinal detachment is present, including those cases with epiretinal membrane formation, marked vitritis, active retinitis, macular hole, or multiple large posterior tears, then pars plana vitrectomy, endolaser photocoagulation, and long acting retinal tamponade have a good chance of reattaching the retina. The visual recovery in these successfully reattached eyes depends on viral infection of the optic nerve, hypotony, macular hole formation, and postoperative epiretinal membrane formation.

I Blumenkranz MS, Culbertson WW, Clarkson JG, Dix R. umenkranz MS, Culbertson WW, Clarkson JG, Dix R. Treatment of the acute retinal necrosis syndrome with

2 Saari KM, Bake W, Mauthey KF, et al. Bilateral acute retinal necrosis. Ophthalmology 1982; 93: 403-11.

3 Topelow HW, Nussbaum JJ, Freeman HM, Dickerson GR Szyfelbein W. Bilateral acute retinal necrosis, clinical and ultrastructural study. Arch Ophthalmol 1982; 100: 1901-8.

4 Sternberg P Jr, Know DL, Hinkelstein A, Green WR, Murphy RP, Patz A. Acute retinal necrosis syndrome. Retina 1982; 2: 145-51.

5 Price FW Jr, Schlaegel TF Jr. Bilateral acute retinal necrosis syndrome. Am f Ophthalmol 1980; 89: 419-24.

6 Young NJA, Bird AC. Bilateral acute retinal necrosis. $\mathrm{Br} f$ Ophthalmol 1978; 62: 581-90.

7 Willerson D Jr, Aaberg TM, Reiser FH. Necrotizing vasoocclusive retinitis. Am f Ophthalmol 1977; 84: 209-19.

8 Gorman BD, Nadel AJ, Coles RS. Acute retinal necrosis. Ophthalmology 1982; 89: 809-14.

9 Culbertson WW, Clarkson JG, Blumenkranz M, Lewis ML Acute retinal necrosis. Am $\mathcal{f}$ Ophthalmol 1983; 96: 683-5.

10 Urayama A, Yamada N, Sasaki T, et al. Unilateral acute uveit with retinal periarteritis and detachment. $\mathcal{F} p n \mathcal{F}$ Clin Ophthalmol 1971; 25: 607-19.

11 Freeman WR, Thomas EL, Rao NA, et al. Demonstration of herpes group virus in acute retinal necrosis syndrome. $A m \mathcal{F}$ Ophthalmol 1986; 102: 701-9.

12 Jabs DA, Schachat AP, Liss R, Knox DL, Michels RG. Presumed varicella zoster retinitis in immunocompromised patients. Retina 1987; 7:9-13.

13 Friberg TR, Jost BF. Acute retinal necrosis in an immunosuppressed patient. Am $\mathcal{F}$ Ophthalmol 1984; 98: 515-7.

14 Jampol LM. Acute retinal necrosis syndrome. Am $\mathfrak{J}$ Ophthalmol 1982; 93: 254 .

15 Ludurg IH, Zegarra H, Zakov N. The acute retinal necrosis syndrome, possible herpes simplex retinitis. Ophthalmology 1984; 91: 1659-64.

16 Yeo JH, Pepose JS, Stewart JA, Sternberg P Jr, Liss RA. Acute retinal necrosis syndrome following herpes zoster dermatitis. Ophthalmology 1986; 93: 1418-22.

17 Matsuo T, Date S, Tsuji T, et al. Immune complex containing herpes virus antigen in a patient with acute retinal necrosis. Am F Ophthalmol 1986; 101: 368-71.

18 Soushi S, Ozawa H, Matsuhashi M, Shemazaki J, Saga V, Kurata $T$. Demonstration of varicella-zoster virus antigens in the vitreous aspirates of patients with retinal necrosis in the vitreous aspirates of patients with

19 Culberston WW, Blumentranz MS, Haines H, Gass JDM Mitchell KB, Norton EWD. The acute retinal necrosis syndrome. Part 2: Histopathology and etiology. Ophthal mology 1982; 89: 1317-25.

20 Culberston WW, Blumenkranz MS, Pepose JS, Stewart JA, Curtain VT. Varicella-zoster virus is a cause of the acute retinal necrosis syndrome. Ophthalmology 1986; 93: 559-69.

21 Rungger-Bundle E, Roux L, Leuenberger J. Bilateral acute retinal necrosis (BARN): identification of the presumed infectious agent. Ophthalmology 1984; 91: 1648-58.

22 Browning DJ, Blumenkranz MS, Culbertson WW, et al. Association of varicella zoster dermatitis with acute retinal necrosis syndrome. Ophthalmology 1987; 94: 602-6.

23 Lewis ML, Culbertson WW, Post JD, Miller D, Kokame GT, Dix RD. Herpes simplex virus type 1 , a cause of the acute retinal necrosis syndrome. Ophthalmology 1989; 96: 875-8. 24 Clarkson JG, Blumenkranz MS, Culbertson WW, Flynn HW Jr, Lewis ML. Retinal detachment following the acute Jr, Lewis ML. Retinal detachment following the acute
retinal necrosis syndrome. Ophthalmology 1984;91: 1665-7.

25 Han DP, Lewis H, Williams GA, Mieler WF, Abrams GW Aaberg TM. Laser photocoagulation in the acute retinal necrosis syndrome. Arch Ophthalmol 1987; 105: 1051-4. 
26 Ando F, Kato M, Gato S, Kobaayashi K, Ichikawa W, Kamiya T. Platelet function in bilateral acute retinal necrosis. $A m \mathcal{F}$ Ophthalmol 1983: 96: 27-32.

27 Schulman J, Peyman GA, Liu J, Scott M, Barber JC. The intraocular penetration of acyclovir after subconjunctival administration. Ophthalmic Surg 1984; 18: 111-4.

28 Schulman JA, Peyman GA, Fiscella RG, Puledo J Sugar J. Parenterally administered acyclovir for vira retinitis associated with AIDS. Arch Ophthalmol 1984; 102 1750.

29 Peyman GA, Goldberg MF, Uninsky E, Tessler H, Palido J, Hendricks R. Vitrectomy and intravitreal antiviral drug therapy in acute retinal necrosis syndrome. Arch Ophthalmol $1984 ; 102: 1618-21$

30 Sternberg $\mathrm{P} \mathrm{Jr}$, Han DP, Yeo JH, et al. Photocoagulation to prevent retinal detachment in acute retinal necrosis. Ophthalmology 1988; 95: 1389-93.

31 Carney MD, Peyman GA, Goldberg MF, Packo K, Pulido J, Nicholson D. Acute retinal necrosis. Retina 1986; 6: Nicholson D. Acute retinal necrosis. Retina 1986; 6: 32 85-94

Blumenkranz M, Clarkson J, Culbertson WW, Flynn HW, Lewis ML, Young GAM. Vitrectomy for retinal detachment associated with acute retinal necrosis. Am $\mathcal{f}$ Ophthalmol 1988 ; 106: 426-9.

33 Kreiger AE. Management of combined inflammatory and rhegmatogenous retinal detachments (ARN and AIDS). In: Ryan SJ, ed. Retina. St Louis: Mosby, 1989: 591-8.

34 Kreiger AE. Discussion of Clarkson JG, Blumenkranz MS, Culbertson WW, Flynn HW Jr, Lewis ML, Nicholson D. Retinal detachment following the acute retinal necrosi syndrome. Ophthalmology 1984; 91: 1665-8.

35 Matsuo T, Nakayama T, Koyama T. A proposed mild type of acute retinal necrosis syndrome. Am $\mathcal{F}$ Ophthalmol 1988; 105: 579-83.

36 Lewis H, Aaberg TM. Anterior proliferative vitreoretinopathy. Am F Ophthalmol 1988; 105: 277-84.

37 Hayreh MMS, Kreiger AE, Straatsma BR. Acute retinal necrosis. Invest Ophthalmol Vis Sci 1980; 19: 48

38 Wang CL, Kaplan HJ, Waldrep JC, Pulliam M. Retinal neovascularization associated with acute retinal necrosis. Retina $1983 ; 3: 249-52$.

39 Han DP, Abrams GW, Williams GA. Regression of disc neovascularization by photocoagulation in the acute retinal necrosis syndrome. Retina $1988 ; 8: 244-6$. 